\title{
MarginalisedBodo people in Education by the Government-A Sciological Study
}

\author{
Chithumbasumatary \\ Deptt.of Sociology Aus
}

\section{Introduction:}

"Education is something which ought to be brought within the reach of every one."

"The object of primary education is to see that every child that enters the portals of a primary school does leave it only at a stage when it becomes literate and continues to be literate throughout the rest of his life."

\section{-B.R. Ambedkar}

The term "Marginalization" generally describes the overt actions or tendencies of human societies whereby those perceived as being without desirability or function are removed or excluded (i.e., are "marginalized"...) from the prevalent systems of protection and integration, so limiting their opportunities and means for survival. Education was perceived as crucial to processes of planned change. It was seen as the key instrument for bringing about a social order based on value of equality and social justice.

Expansion and democratization of the education system was sought, the two primary egalitarian goals of which were the universalisation of elementary education and the educational "upliftment" of disadvantaged groups. The State's special promotional efforts have undoubtedly resulted in educational progress for the SC/ST especially in regions where policy implementation combined with the dynamism of reform, and most crucially with anticaste, dalit, tribal and religious conversion movements.

India is a welfare State, committed to the welfare and development of its people and of vulnerable sections in particular. The preamble, Directive Principles of State Policy, Fundamental Rights and specific sections, viz., Articles 38, 39 and 46 in the Constitution of India, stand testimony to the commitment of the State to its people. Socially disadvantaged groups of Scheduled Castes/ Scheduled Tribes have received special focus over the years for their social and economic advancement. Government has taken several steps for framing appropriate policies needed to design and implement various welfare programmes for achieving the objective of creating favorable environment to ensure speedy socio economic development of SCs/ STs. For the wellbeing of these communities, special target-oriented programmes are being implemented by earmarking funds, providing subsidies, offering reservations in employment and educational institutions etc.

\section{Bodo people and Education:}

Ethnicity and identity have been the key issues of mobilisation in all of north-east India. The region has had a long history of being marginalised; its inclusion in the Indian nation is seriously challenged by communities; and identity politics has shaped the politics of resistance. The struggle for power, both political and economic, has thus become bloodied. The failure of the Sixth Schedule to deliver, the contest over and resources, the lack of development, and the fear of disempowered smaller groups are all tangled in the web of electoral politics of the ruling classes.

It is known that, the All Bodo Students Union since its inception in 1967 has been raising the voice for inclusion of the Bodos and other tribes of Assam in the process of Universal access to Education, SocioEconomic and Political right. In fact, the All Bodo Students Union had demanded Educational and SocioEconomic development before launching the famous democratic political movement for a separate state of Bodoland on the 2nd March 1987. The visible discrimination of the ruling elites of Assam in setting up education institutions right from lower primary school to University had forced the union to resort to political demands so that all problems could be resolved without the intrusion of biased elites.

The discrimination has reached to such an extent that the Bodo medium schools despite being introduced in the year 1963 a total of 842 lower primary schools, 373 Middle English schools and 218 high English schools are functioning without a single penny of government support as venture schools. These schools in absence of any support are functioning in an abysmal condition depriving lack of children from quality education, Mid-Day Meal, adequate text books and other Government Facilities. The teachers are completely demoralized because they do not get a single paisa or payment from the schools. The infrastructures in the schools are in an unimaginable state, it is really disheartening to see that many of the teachers have retired without any remuneration. The newspaper report shows that many of teachers from venture schools were committing suicide. 
All these are happening despite being aware of Article 46 of the directive principle. The recent recognition of Educational Rights as Fundamental Rights under the Article 21(a) also seems to be non-applicable to Bodo students. The fundamental right to equality before Law under article 14 also seems to be in vain in case of the Bodo as despite being in the same land Bodo has been treated unequal.

If the Educational condition in the Primary and Secondary level is in this shape, one couldn't imagine of higher Education. There are 3 million (30 lakh) of population in Bodo Territorial Council area whereas Bodo have only 08(eight) degree colleges and 5(five) junior Arts colleges which are provincialised against the 26 (Twenty Six) non provincialised degree colleges and 13 (thirteen) junior non provincialised Arts colleges. There are total 7 (Seven) science non provincialised colleges and 3 (three) non provincialised commerce colleges. The long standing demand and aspiration of people living in Bodoland region for a Central University has been discarded by Government of India at the juncture when other places are dumped with institutions of higher Education. The Medical College and Agriculture College seems to a costly dream for the Bodos.

The consolidation of the Indian state in so far as its coercive instrumentalities are concerned, along with its increasing indifference to and marginalisation in matters of development benefiting all sections of the people, is a fact that is blazingly evident.

The BodoSahityaSabha (BSS) has urged upon the government of Assam to solve the problems of the Bodo medium schools in the State and for giving ample scope for the upliftment of Bodo language and literature.

The General Secretary of the BSS said the Sabha has been working for the all-round development of the Bodo medium schools and enrichment of Bodo language and literature since the foundation of the BSS on November 16, 1952 at Basugaon in undivided Kokrajhar district, now in Chirang district. He said the Sabha will discuss mainly on the Bodo medium related problems as the government has not taken necessary steps to solve the problems of Bodo medium. He said over 70 per cent schools of Bodo medium are yet to be provincialized and most of the schools do not have Mathematics and Science teachers.(The Sentinal,22/03/13).

The Bodo medium venture schools have the largest contribution in providing education to the Bodo students but these schools have lack of teachers, he said adding that the government should provincialize the Bodo medium schools across the State for survival of Bodo medium.

The Education is the Fundamental Right which is included in the Article 21A of the Constitution of India; this fundamental right is made more worthy under The Right of Children of Free and Compulsory Education Act, 2009. The Act ensures the children from age of 6-14 years, for free and compulsory education. However, the All Bodo Students"e Union (ABSU) in a statement sent by the General Secretary and Education Secretary said in many tribal areas of Assam children are deprived from getting free and compulsory education. In the recent Provincialisation of the LP, UP and Secondary and Higher Education the Provision in the case of the elementary education which the RTE ensures that all the schools must be recognized and provincialized by the government as in the provision under Section $6 \& 7$ of the RTE Act, the statement said adding that the Provision in The Assam Venture Educational Institutions (Provincialisation of Services) Act, 2011, provides the terms and conditions which contradicts the Fundamental Right to education in the elementary level.

The All Bodo Students" Union (ABSU) said the land issue is the fundamental right is inherent to the land where the persons are living. Therefore for the schools in the forest areas established and recognized must be provincialized as the land permit from the forest or any department cannot remain a hurdle in enjoying the Fundamental Right of Education; there is also a provision in the Schedule Tribes and other Traditional Forest

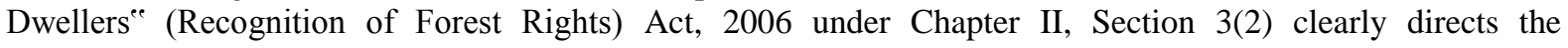
government of India and the State to allot land for the schools and other welfare projects for the ST and traditional forest dwellers people dwelling in the forest region. In fact, denying the rights of the tribes forest rights in Assam is very much condemnable.

Mixed-medium (Bodo and Assamese) type of schools must not be left apart and only one medium must be provincialized when the recognition year and establishment is in the same year which will be a discriminatory to the vernacular medium of Bodo.

On the distribution of free text-books, the ABSU said the government of Assam must be very sincere on the implementation of the Fundamental Right of Education to all sections of society and medium of instructions. The Union rejects the policy of not sending extra textbooks or the office copy in the LP \& UP schools; which is a hindrance to the teacher to impart proper education lacking the opportunity to self-study. The other concern is RTE ensures admission of children in any LP \& UP schools at any time of the academic year; therefore books must be available at the schools for quick access for the quality education and ensuring fundamental rights. As all children are entitled to free and compulsory education from the age of 6-14 years, all children despite in private must get free textbooks all over the State.

Moreover, the Government of Assam has not maintained and provincialized all the venture institutions without any condition since four decades. The Bodo medium schools were deprived from having insufficient teachers. However, in such a condition of the functioning of the venture institutions how can there be a 20 
percent pass percentage maintained in that teacher less Bodo Medium Institutions? The government of Assam has done atrocities to the tribal community neglecting the backwardness and inability to quality education. The union demanded for the tribal venture institutions to be provincialized immediately. The All Bodo Students ${ }^{\text {ee }}$ Union (ABSU) has reacted strongly to the proposal of Assam Education Minister HimantaBiswaSarma to conduct separate TET for the tea garden areas and tribal students.

The Union president and general secretary said, although the Union has been demanding holding of separate TET for Bodo medium schools in Assam, the government has no intention of developing Bodo medium schools and this has come light with the recent announcement of the Education minister.

PramodBoro said, "The Union has been demanding development of Bodo medium since the last six decades. Bodos are not against development of other communities or areas, but the government has totally ignored our demand by giving preference to certain communities and areas over others."

\section{Conclusion:}

Since the level of educational attainment plays a 'linchpin' role in reducing the incidence of poverty as well as improving the health status of the socially marginalized and economically disadvantaged sections of the society, the need to provide adequate and qualitative education in rural areas, and especially to the weaker sections of the society.

Assam Government showing apathy in implementation of Bodo language as one of the state official language. The Bodo Language is one of the National languages after inclusion of it into the 8th Schedule of the Indian Constitution. It is medium of instruction in Assam, full-fledged department in Gauhati University and MIL in many other Universities including NEHU. But still this language has myriad of problems including survival as medium and development of language and literature. The main reasons are totally negligible financial support from the state Government, lack of proper planning and absence of proper institutional mechanism. But after long eight years of experiment on the line of BAC formed in the year 1993 Bodo have experienced that it is creating more chaotic situation rather than solution in all the matter related to education, socio-political and law and order. The Bodos were optimistic that the maximum problems faced by the Bodo community would be resolved with the formation of BTC in 2003. In the true sense of term it is said that every people is equal in the eyes of law and justice should be given to the people to maintained peace and tranquility in the state. But all these are happening exactly opposite in BTC.

\section{References :}

[1]. Brahma Rustam, Conteporary problems of Bodo Society- A Study with special reference to Kokrajhar, Kokrajhar 2010.

[2]. Choudhary, Kameshwar. "Dalits in Higher Education: Cooption or Domination", Journal of Higher Education, Vol. 21.No. 3, Monsoon 1998. 5. Gore, M.S., I.P. Desai, and S. Chitnis, Field Studied in the Sociology of Education, All India Report, NCERT, New Delhi, 1970.

[3]. Endle, Rev. Sidney, TheKacharies, Law Price Publication, Delhi, 1990

[4]. Garg, Arun. : Foundations of Sociology, Global Vision Publishing House, New Delhi, 2010.

[5]. Narzary, Bonny, History and Culture of the Bodos, Kolkata, 2011.

[6]. Sahay, Lalit K.: Ambedkar and Caste System, Mohit Publication, New Delhi, 2010.

[7]. Thakur, G.S Sarma, Saikia M.C, Bordoloi B.N, Tribes of Assam Part-I, II, III in BN Bordoloi, Guwahati, 1987.

[8]. Shah, B.V.: "Inequality of Educational Opportunities", Economic and Political Weekly, August 20, 1960.

[9]. Singhi. : Education and Social Change, Rawat Publication, 1979

[10]. http://www.businessdictionary.com/definition/marginalization.html

[11]. http://www.excellup.com/classeight/sseight/marginalisationeight.aspx

[12]. http://www.sociologyguide.com/civil-society/development.php

[13]. http://www.sociologyguide.com/civil-society/marginalization.php 